The University of San Francisco

USF Scholarship: a digital repository @ Gleeson Library |

Geschke Center

Economics, Law, and International Business

School of Management

1986

\title{
Intra-Industry Joint Liability: Implications for Marketing
}

Karl Boedecker

University of San Francisco, boedecker@usfca.edu

Fred W. Morgan

Follow this and additional works at: http://repository.usfca.edu/elib

Part of the Business Law, Public Responsibility, and Ethics Commons, and the International Business Commons

\section{Recommended Citation}

Karl Boedecker and Fred Morgan, “Intra-Industry Joint Liability: Implications for Marketing,” Journal of Public Policy \& Marketing, 5, 72-84. 1986

This Article is brought to you for free and open access by the School of Management at USF Scholarship: a digital repository @ Gleeson Library | Geschke Center. It has been accepted for inclusion in Economics, Law, and International Business by an authorized administrator of USF Scholarship: a digital repository@Gleeson Library| Geschke Center. For more information, please contact repository@usfca.edu. 


\title{
Intra-Industry Joint Liability: Implications for Marketing
}

\author{
Karl A. Boedecker \\ Fred W. Morgan
}

KARL A. BOEDECKER is Professor of Marketing at the University of San Francisco, San Francisco, CA 94117 and Fred W. MORGAN is Professor of Marketing at Wayne State University, Detroit, MI 48202.
Market share liability is the most recent product liability development in the area of intra-industry joint liability, in which all members of an industry are sued. The various intra-industry approaches by which a consumer can recover for injuries are reviewed in this article, and their implications for marketing are examined.

Current litigation of claims against an entire industry, or its dominant members, has resulted in important developments in product liability law that, in turn, raise substantial implications for marketing. The most highly publicized and critically analyzed cases involve diethylstilbestrol (DES), a synthetic estrogen frequently prescribed between 1945 and 1971 for women to prevent miscarriages and other accidents of pregnancy [Sindell v. Abbott Labs 1980, Payton v. Abbott Labs 1979, Reed and Davison 1982]. Similar litigation has occurred or is pending with regard to asbestos [Insurance $\mathrm{v}$. Forty-Eight 1980, Newsweek 1982, Wall Street Journal 1983], insulation [Davis v. Yearwood 1980], aluminum wiring [Beverley Hills 1979], leaded paint [U.S. News \& World Report 1982], herbicides and pesticides [Business Week 1984, Newsweek 1984, Time 1984], and food additives such as nitrates and nitrites.

The common factor in all of these cases is the exceptionally long lapse of time between product use and resultant injuries, making it very difficult for the plaintiff to prove which manufacturer(s) made the defective product. Given this problem of proof, the California Supreme Court developed a theory of recovery, called market share liability, in which DES manufacturers were held liable for damages according to their relative market shares [Sindell v. Abbott Labs 1980]. Market share liability is the most recent development in the area of intra-industry joint liability in which several firms in an industry are sued simultaneously.

The adoption of a market share liability approach may, however, lead to serious problems as it is applied to current cases. In addition, the rekindling of interest in intra-industry joint liability because of Sindell has resulted in the reexamination of earlier theories of joint liability by legal scholars [Leibman 1983, 1984, LaMarca 1982, Dworkin 1981a, HLR 1980, Sheiner 1978]. In spite of having been developed several years ago [Steffen 1965, Harper and James 1956], these other theories of recovery from multiple defendants have not been adequately studied from a marketing perspective.

Hence, this article first considers the nature of the DES situation to present the important elements of an intra-industry joint liability claim. Next, all of the approaches to joint liability are reviewed in the context of DES and other related cases. Finally, the implications of market share liability for marketing are discussed. 
The Nature of the DES Problem

An estimated one-half to two million women took DES between 1947, when the Food and Drug Administration (FDA) approved its use for prevention of accidents related to pregnancy, and 1971, when the FDA withdrew approval for use by pregnant women. As many as four million female offspring were exposed to DES [Henderson 1980, p. 143]. The FDA categorized DES as experimental and required it to be so labeled when distributed [Dworkin 1981b, p. 77].

Although DES was considered both safe and effective at the time of its introduction, medical researchers subsequently discovered that daughters of DES users had an unusually high incidence of precancerous condition and rare forms of cancer. Nor was DES shown to be effective for the prevention of miscarriages.

Somewhere between 94 and 300 companies produced DES during the 20 years prior to the discovery of the drug's adverse consequences [Sheiner 1978 , p. 964]. No firm held a patent on DES because it was a generically marketed product, and pharmacists could fill prescriptions with the product of any manufacturer [Payton v. Abbott Labs 1979]. Many of these firms sold DES for uses other than, or in addition to, accidents of pregnancy. DES continues to be prescribed for a number of health-related problems.

The above factors combine to create unique problems for DES plaintiffs who seek recovery in product liability litigation. When more than 100 firms have marketed a product which may have caused injuries which become apparent only after 10 to 20 years following plaintiffs' prenatal exposure, there are difficult problems regarding proof of facts. More specifically, a plaintiff will encounter difficulty in attempting to identify, perhaps 25 years after her mother had consumed the product, which pharmaceutical firm manufactured the drug that caused her injuries.

All of these considerations relate to the issue of intra-industry joint liability: under what conditions may a plaintiff sue an entire industry, or the major members thereof, to assess liability for a defective product whose exact origin is unknown [Kroll 1979, p. 193]? Industry-wide liability was conceived initially as a technique for apportioning damages among several defendants, but only after a plaintiff had proven them all to be liable. However, recent decisions have begun to use industry-wide liability as a means of assisting the plaintiff to demonstrate liability [Abel v. Eli Lilly 1980, p. 31, Sindell v. Abbott Labs 1980, pp. 614-22]. The resultant blurring of the damage apportionment and liability assessment functions can create considerable confusion.

Such problems and disorder have led DES plaintiffs to attempt novel applications of traditional approaches to tort recovery and to propose new arguments upon which to base claims of joint liability [Mink v. University 1978, Morrissy v. Eli Lilly 1979, Katz v. Eli Lilly 1979]. Some courts have responded by stretching the doctrines of alternative liability and concert of action in order to help plaintiffs overcome their problems of proof [Abelv. Eli Lilly 1980, Ferrigno v. Eli Lilly 1980]. Others have heard a variety of arguments on behalf of an enterprise liability approach [Sindell v. Abbott Labs 1980, Abel v. Eli Lilly 1980]. And California has opted for a market share basis for recovery [Sindell v. Abbott Labs 1980]. These four intraindustry theories of recovery are now described in detail.

Approaches to Joint Liability
Traditional approaches to joint tort liability include alternative liability and concert of action. At least one court has held that DES plaintiffs can bring actions under either of these theories [Abel v. Eli Lilly 1980]. 
Alternative Liability

Concert of Action

Concert of Action
or design to commit a harmful act who (a) actively take part in it,(b) further it by cooperation or request, (c) lend aid or encouragement to the wrongdoer, or (d) ratify and adopt the wrongdoer's acts done for their benefit are equally liable [Prosser 1971, p. 592].

Although drag races are the most frequently mentioned examples of concerted action [Bierczynski v. Rogers 1968], it could apply to product liability suits where the plaintiff can cite parallel actions by defendants in order to make inferences of a plan or tacit agreement [Orser v. George 1967]. Such actions might include manufacturing a product to common designs and specification, industry-wide activities with regard to product safety and warnings, and other common efforts, perhaps through a trade association, such as lobbying. At least one court has maintained, however, that a plaintiff must demonstrate some "joint control of the risk" by defendants to prove joint control [Hall v. DuPont 1972, p. 37]. Although the plaintiff need not establish a formal joint venture on the part of the defendants to prove joint control [Connor v. Great Western 1968], evidence of shared research, joint testing of products, and joint legislative lobbying or trade association should be provided at the very least.

As with an assertion of alternative liability, concerted action on the part of the defendants shifts the burden of proof to them. In order to evade liability, any defendant must prove that its actions were not connected to the plaintiff's injury.

In Sindell the defendants were charged with having (a) failed to test DES adequately, (b) not provided sufficient warnings, (c) relied upon the tests performed by one another, and (d) taken advantage of one another's promotion and marketing techniques. The court maintained that these allegations did not amount to a charge of tacit understanding or a common plan. Further, it could not be established either that each defendant knew the other's conduct was harmful to the plaintiff or that defendants had helped or encouraged one another with regard to inadequate testing and warning.

Enterprise Liability Experts who disagree with the extension of traditional theories of joint tort liability to allow for industry-wide liability have proposed that courts adopt 
the enterprise liability doctrine [Sheiner 1978; Podgers 1980, Klemme 1976]. This approach would modify alternative liability in that a plaintiff would have to prove a "high probability" that the injury resulted from unjust behavior by one of the defendants. As described in one often-cited source, the specific elements of enterprise liability would be [Sheiner 1978, p. 995]:

1. Plaintiff is not at fault for his inability to identify the causative agent and such liability is due to the nature of the defendant's conduct.

2. A generically similar defective product was manufactured by all the defendants.

3. Plaintiff's injury was caused by this product defect.

4. The defendant owed a duty to the class of which plaintiff was a member.

5. There is clear and convincing evidence that plaintiff's injury was caused by the product of some one of the defendants. For example, the joined defendants accounted for a high percentage of such defective products on the market at the time of the plaintiff's injury.

6. There existed an insufficient, industry-wide standard of safety as to the manufacture of this product.

7. All defendants were tortfeasors satisfying the requirements of whichever cause of action is proposed: strict liability, negligence, or warranty.

Defendants unable to prove that their products could not have caused the injury would pay damages according to their market shares [Sheiner 1978, p. 994]. The justification for this enterprise liability basis for industry-wide liability rests upon the following policy argument [Sheiner 1978, pp. 1002-4]:

Where an entire industry, engaged in a predictably dangerous enterprise and following similar safety practices, places an identically defective product in the stream of commerce, the industry rather than the individual manufacturer should be the focal point for liability because it can best allocate risks, distribute costs, and take preventive measures.

In Hall v. DuPont [1972], six explosives manufacturers and their trade association were held liable for injuries resulting from blasting cap accidents. The court said that where individual manufacturers could not be identified, the existence of industry-wide standards or practices could support a finding of joint control of the risk, thereby shifting to each defendant the burden of proving its product could not have injured the plaintiffs. The question of whose blasting caps caused the harm became secondary to the court's finding that defendants engaged in joint control of the risk. So in situations where a plaintiff cannot identify which defendant manufactured the harmful product and each defendant is equally unable to prove that its product did not cause the injury, liability will follow.

The Hall court took care, however, to place some limits on the possible scope of its opinion [Hall v. DuPont 1972, p. 378]:

By noting these requirements, we wish to emphasize their special applicability to industries composed of a small number of units. What would be fair and feasible with regard to an industry of five to ten producers might be manifestly unreasonable if applied to a decentralized industry composed of thousands of small producers.

The Sindell court, using Hall for guidance, declined to apply enterprise liability to the DES situation for three reasons. First, at least 200 firms had marketed DES during the period in question while the six companies in Hall comprised virtually the entire blasting cap industry in the U.S. Second, DES manufacturers had not jointly controlled the risk via trade associations. Last of all, the pervasive role of the FDA in setting criteria for testing 
Market Share Liability

Implications of Joint Liability Litigation

Difficulties in Applying Market Share Liability and marketing drugs made it unfair to impose liability without proof regarding who supplied the offending DES.

The California Supreme Court, under the new doctrine it designated as market share liability, sustained the Sindell plaintiff's cause of action by adapting the alternative liability rule described earlier [GLR 1981, Land and Melham 1981, Kroll 1980]. The market share approach to intra-industry joint liability includes at least the following elements [Sindell v. Abbott Labs 1980]:

1. Plaintiffs suffered injury because of a defectively designed product marketed by some unknown manufacturer.

2. Plaintiff's inability to identify the specific manufacturer arose through no fault of his/her own.

3. All manufacturers in the industry produced and marketed the same product with an identical design defect.

4. Plaintiff joined as defendants those firms which accounted for "a substantial share of the market."

If a plaintiff can establish the above elements, each defendant must then try to show that it could not have been the source of the harmful product. Since shifting this burden to defendants is tantamount to determining whether plaintiffs or defendants will most probably prevail, the court has apparently decided that the costs of DES injuries should be shared by those surviving DES producers whom plaintiffs can bring before a California court. The court relied on the Summers rationale that, as between an innocent plaintiff and negligent defendants, the latter should bear the cost of injury [Brahn 1980].

Additional policy-based reasons offered for the Sindell decision included the belief that defendants are better able to bear the cost of injury and that manufacturers are in the best position to guard against defects and to provide warnings; therefore, holding them liable for not adequately performing those tasks provides an incentive for product safety [Burch 1982, p. 789]. The court also noted the desirability of fashioning new remedies to meet the changing needs of a complex industrial society and corresponding necessity of adapting the rule of causation and liability [Sindell v. Abbott Labs 1980, pp. 601-11]. The court seemingly based its decision on policy grounds rather than having deduced it as the inevitable outcome of applying and extending existing legal doctrines to the DES problem.

The court's general statement of the market share liability rule for the apportionment of damages in DES cases creates several serious difficulties for companies involved in such litigation. Moreover, implications for the marketing system arise from the potential explosive growth in the area of intra-industry joint liability.

As articulated by the court, the market share rule provides that [Sindell $\mathrm{v}$. Abbott Labs 1980, p. 612]:

Each defendant will be held liable for the proportion of the judgment represented by its share of that market unless it demonstrates that it could not have made the product which caused plaintiff's injuries....

Under this approach, each manufacturer's liability would approximate its responsibility for the injuries caused by its own products. 
At the outset, this statement raises several questions about the appropriate definition of "market share." Because manufacturers' market shares probably varied between 1947 and 1971, will different market shares apply for different plaintiffs according to when their mothers used DES? Or should an average market share be calculated for the entire period? If so, what about the fact that many firms produced DES for only part of the 1947-to-1971 period?

Market share issues also arise with respect to geographic area. Which market figures apply if a firm with a large share of the national market had a much smaller share within the state where the plaintiff's mother consumed the drug, or vice versa? This difficulty is compounded if some companies have gone out of business or operate beyond the reach of the courts within the state trying the lawsuit.

The fact that several manufacturers marketed DES for uses other than the prevention of accidents of pregnancy further complicates the issue. Measuring market shares according to the total volume produced or sold could overstate the liability of firms whose product was used for other purposes.

Additional market share computation problems may occur if the plaintiffs bring pharmacists and drug wholesalers as defendants in DES actions along with manufacturers. The Sindell decision addresses only the division of liability on a horizontal basis, i.e., among manufacturers. Vertical allocations, i.e., among manufacturers, wholesalers, distributors, and retailers, lead to more complex problems. For example, a plaintiff might join as defendants four manufacturers with 60 percent of industry output, three wholesalers handling 35 percent of the product within the state having jurisdiction, and a chain store retailer that accounted for 15 percent of DES sales throughout the state. While the nonadditive nature of market shares on a vertical basis explains the 110 percent "total" market share figure, it still leaves the court without a market share rule in such cases.

In a similar vein, the lack of specificity as to what constitutes a "substantial share of the market" on the part of DES codefendants may lead to other questionable consequences. Recovery is permitted from several defendants, each of whom may account for a relatively small market share, as long as their combined shares are deemed "substantial." The dissenting opinion in Sindell expresses serious reservations about the equity of this situation [Sindell v. Abbott Labs 1980, pp. 615-16].

Implications for Marketing

New Product Development
The market share liability rule, to the extent that it applies to domestic drug manufacturers, makes the pharmaceutical industry an insurer of DEScaused injuries. The resulting exposure is potentially staggering. One New York court entered a $\$ 500,000$ jury verdict for a DES victim in an intraindustry joint liability suit [Bichler v. Eli Lilly 1981]. While not all DES cases may be worth one-half million dollars, about four million women were exposed to DES [Henderson 1980, p. 143]. The implications of such outcomes, or even the prospect of such outcomes, for marketing are considerable and diverse.

The extension of liability for injuries which surface a generation after product use and for which causation need not be proven greatly increases the financial risk of introducing new products. One likely response to this situation will be more elaborate and expensive testing procedures prior to marketing such products. Further, duplicate testing of new products by pharmaceutical manufacturers is likely to occur to avoid the possibility of "jointly controlling the risk." 
An additional implication is the inevitable rise in product liability insurance rates. Indeed, given the uncertainties involved in predicting risks and expected losses for this sort of liability, the risk may become unratable. The relatively underdeveloped state-of-the-art of generational testing of food and drug products further exacerbates the insurance problem.

The net effect of these cost-raising factors will be the tendency of the pharmaceutical industry to slow product development, perhaps even abandoning controversial products because of the risks involved. But the potential impact of market share liability extends well beyond the pharmaceutical industry. Consider the possibility of applying this doctrine to other widely-used chemicals, such as asbestos. Asbestosis and similar respiratory diseases including lung cancer become apparent ten or more years after the initial exposure to the substance [Insurance v. Forty-Eight 1980]. Just as with DES, the injured person will probably be unable to identify the particular manufacturer who produced the offending product. Or, as is more likely to occur, the worker may have been exposed to asbestos supplied by several companies.

Should the market share approach be extended to these asbestos-related injuries, substantial exposure on the part of the asbestos manufacturers would result. Over 3,000 different products contain asbestos, ranging from consumer items such as toothbrushes and hair dryers to industrial goods such as asphalt and concrete water pipes. An estimated eight to eleven million workers have been exposed to asbestos since World War II began [Mansfield 1980, pp. 860-66]. The industry faces at least 5,000 bodily injury product liability suits in which defendants include manufacturers, distributors, and other suppliers [Mansfield 1980, p. 865].

Lawsuits arising out of use of herbicides and pesticides manufactured to identical formulas, leaded paint, aluminum wiring [Beverley Hills 1979], insulation [Davis v. Yearwood 1980] offer situations in which the market share liability doctrine seems to fit. Delayed reactions to any of these products are likely to leave plaintiffs in a position where, through no fault of their own, they cannot connect their injuries with one specific producer.

Generic labeling of nondurable products provides many other situations in which an injured person may not be able to identify the faulty product's manufacturer, especially if he/she purchased several unbranded versions of the product. Companies which feel confident that their products pose fewer risks to buyers, perhaps because of more thorough testing, may discard unbranded versions of their products in an attempt to lessen their product liability exposure via the market share approach [Land and Melham 1981, pp. 45-46].

Overall, then, new product development may decline in many industries where products are similar, especially if distinctive brand identities have not been established.

Channel Integration The growth of market share liability litigation could lead to greater cooperation within the channel as well as attempts by the most vulnerable channel members to control channel operations. Thus, the tendency toward vertical marketing systems [Kotler 1980, p. 425] is likely to be stimulated.

Fewer, larger manufacturer-distributor combinations will be better able to withstand the financial impact of intra-industry joint liability lawsuits. The economies of such large-scale operations may even allow the participating firms to self-insure should intra-industry risks become unratable. Smaller firms unable to withstand the financial impact of such a suit will be either forced out of business or compelled to become members of substantially larger distribution channels. 
Current problems experienced by a channel member in seeking indemnification from other members will also lead to increased channel integration. Eaton, the manufacturer in Wetzel v. Eaton [1973], an alternative liability case, experienced difficulty in identifying which of two component parts suppliers had manufactured the part which had failed, causing Wetzel's injuries. Intra-industry joint liability theories of recovery are usually invoked when plaintiffs have no way of identifying the specific defendant whose product caused the injuries. But the court in Wetzel noted that Eaton clearly should have maintained records regarding which component supplier made the faulty part [Wetzel v. Eaton 1973, p. 30]. Thus, even if they do not have records, manufacturers may be held to have such knowledge, preventing them from using joint liability theories to recover from their suppliers [Summers v. Tice 1948]. As a result, manufacturers may begin to monitor the actions of their suppliers more closely, perhaps demanding assurances about the quality of the supplied component or assuming some of the testing and inspecting functions.

\section{Marketing-Law Research}

Both marketing theorists and practitioners should begin to study a basic question relating to intra-industry joint liability: How will the definition of a fungible product change as courts begin to consider consumer behavior research?

This question is actually one of perspective. Intra-industry theories of recovery are relevant when the injury-causing product cannot be traced to a particular company. Thus, the product is indistinguishable as to its source. If several firms use the same chemical formula or production process, the resulting products are said to be fungible [Nolan 1982]. But the viewpoint is that of the manufacturer.

If courts begin to consider what products consumers regard as substitutes (a market-related definition of fungible), more products could come under the scope of intra-industry liability [Dworkin 1981a, p. 80]. If products' brand identities are not established and if a particular product is destroyed, preventing the manufacturer from being named, while harming a user, what will the courts do? Perhaps opinion polls will show that this product belongs to a class of goods that consumers regard as being undifferentiated. As consumer behavior research gains acceptance in product liability litigation [Morgan and Avrunin 1981], the term "fungible" could take on expanded meaning, thereby broadening the scope of intraindustry liability.

Summary The major implications for marketing of the evolving trends in intraindustry joint liability have been highlighted. The legal implications and problems have necessarily been simplified because of their technical complexity and lack of direct relevance.

All of the issues mentioned seem to point to the need to balance the injured parties' rights to recover damages against the defendants' concerns about maintaining the extent of liability within reasonable bounds. Modern technology has brought about the production and marketing of increasingly sophisticated products which can cause injuries via complex, unprecedented processes that may leave the injured party unable to identify the specific cause of the harm. As a matter of social policy, the law can allow those injuries to be borne by the parties which incur them or it can allow for some form of compensation by fashioning contemporary rules for recovery [Dworkin and Zollers 1982]. Since "the market is the ultimate laboratory, 
and the consumer is the ultimate test subject" [Wilson 1980, p. 757], the latter option seems much more acceptable.

References Abel v. Eli Lilly \& Company (1980), 289 N.W.2d 20, 94 Mich.App. 59.

Beverley Hills Fire Litigation (1979), Civil No. 77-79 (E.D. Ky).

Bichler v. Eli Lilly \& Company (1981), 79 A.D.2d 317, 436 N.Y.S.2d 625.

Bierczynski v. Rogers (1968), 239 A.2d 218 (S.D. Del.).

Brahn, Kathleen M. (1980), "Diethylstilbestrol: Extension of Federal Class Action Procedures to Generic Drug Litigation," University of San Francisco Law Review, 14 (Spring), 461-93.

Burch, Jr., Francis B. (1982), "Generic Products and the Problem of Identifying the Party Whose Product Caused the Plaintiff's Injury," Forum, 17 (Winter), 784-91.

Business Week (1984), "The Bargaining Behind the Agent Orange Deal” (May 21), 39-40.

Connor v. Great Western Savings \& Loan Association (1968), 69 Cal.2d 850.

Davis v. Yearwood (1980), 612 S.W.2d 917 (Tenn.App.).

Dworkin, Terry M. (1981a), "Enterprise Liability-Increasing the Manufacturer's Burden," Business Horizons, 24 (May-June), 77-82.

(1981b), "Product Liability Reform and the Model Uniform Product Liability Act," Nebraska Law Review, 60 (Winter), 50-80.

and Frances E. Zollers (1982), "Market Share Liability-Proposals for Application," American Business Law Journal, 19 (Winter), 523-38.

Ferrigno v. Eli Lilly \& Company (1980), 175 N.J.Super. 551, 420 A.2d 1305.

Garcia v. Joseph Vince Co. (1978), 84 Cal.App.3d 868, 148 Cal.Rptr. 843.

GLR (1981), "Industry-Wide Liability and Market Share Allocation of Damages," Georgia Law Review, 15 (Winter), 423-50.

Hall v. E. I. DuPont de Nemours \& Co. (1972), 345 F.Supp. 353 (E.D. N.Y.).

Harper, Fowler V. and Fleming James, Jr. (1956), The Law of Torts, Boston: Little, Brown.

Henderson, Jr., James A. (1980), "DES Litigation: The Tidal Wave Approaches Shore," Corporation Law Review, 3 (Spring), 143-48.

HLR (1981), "Market Share Liability: An Answer to the DES Causation Problem," Harvard Law Review, 94 (Jan.), 668-80.

Insurance Co. of North America v. Forty-Eight Insulations, Inc. (1980), 633 F.2d 1312 (6th Cir.).

Katz v. Eli Lilly \& Company (1979), 84 F.R.D. 378 (E.D. N.Y.).

Klemme, Howard C. (1976), "The Enterprise Liability Theory of Torts," University of Colorado Law Review, 47 (Winter), 153-232.

Kotler, Philip (1980), Marketing Management: Analysis, Planning, and Control (4th ed.), Englewood Cliffs, NJ: Prentice-Hall.

Kroll, Elliott M. (1979), "Intra-Industry Joint Liability: A New Era in Products Liability," Insurance Law Journal, 675 (April), 193-210.

(1980), "Intra-Industry Joint Liability: The Era of Absolute Products Liability, Insurance Law Journal, 68 (April), 185-201.

LaMarca, George A. (1982), "Market Share Liability, Industry-Wide Liability, Alternative Liability and Concert of Action: Modern Legal Concepts Preserving Liability for Defective but Unidentifiable Products," Drake Law Review, 31 (Winter), 61-82.

Land, Stuart J. and Maxwell J. Melham (1981), "The New California Market Share Theory in Drug Liability Cases," Food, Drug, and Cosmetic Law Journal, 36 (Jan.), 39-46.

Leibman, Jordan (1983), "Liability for the Unknowable," Business Horizons, 28(July-Aug.), 3540. 
(1984), "The Manufacturer's Responsibility to Warn Product Users of Unknowable Dangers," American Business Law Journal, 21 (Winter), 403-38.

Mansfield, Christophe C. (1980), "The Cases and the Insurance Problem," Forum, 15 (Summer), 860-79.

Mink v. University of Chicago (1978), 460 F.Supp. 713 (N.D. Ill.).

Morgan, Fred W. and Dana I. Avrunin (1982), "Consumer Conduct in Product Liability Litigation: Areas for Application of Consumer Research," Journal of Consumer Research, 9 (June), 47-55.

Morrissy v. Eli Lilly \& Company (1979), 76 Ill.App.3d 753, 394 N.E.2d 1369.

Newsweek (1982), “An Asbestos Bankruptcy” (Sept. 6), 54-55, 57. (1984), “Agent Orange in the Dock" (May 14), 79, 81.

Nolan, Kenneth P. (1982), "Handling Identification Problems in Product Liability Cases," Case \& Comment, 87 (Jan.-Feb.), 44-49.

Orser v. George (1967), 252 Cal.App.2d 660, Cal.Rptr. 708.

Payton v. Abbott Laboratories (1979), 83 F.R.D. 382 (D. Mass.).

Podgers, James (1980), "DES Ruling Shakes Products Liability Fields," American Bar Association Journal, 66 (July), 827.

Prosser, William L. (1971), Law of Torts, St. Paul, MN: West Publishing Co.

Reed, O. Lee and Art Davison (1982), "The DES Cases and Liability without Causation," American Business Law Journal, 19 (Winter), 511-23.

Restatement (Second) of Torts (1965), American Law Institute.

Sheiner, Naomi (1978), "DES and a Proposed Theory of Enterprise Liability," Fordham Law Review, 46 (April), 963-1007.

Sindell v. Abbott Laboratories (1980), 26 Cal.3d 588, 607 P.2d 924, 163 Cal.Rptr. 132.

Steffen, Roscoe (1965), "Enterprise Liability: Some Exploratory Comments," Hastings Law Journal, 17 (Dec.), 165-87.

Summers v. Tice (1948), 33 Cal.2d 80, 199 P.2d 1.

Time (1984), "Winning Peace with Honor: A Truce is Negotiated in the Battle of Agent Orange" (May 21), 39-40.

U.S. News \& World Report (1982), “Toxic Nightmares for Victims” (June 14), 63.

Wall Street Journal (1983), "UNR Case May Set Legal History with Effort to Limit Asbestos Suits" (March 16), 28.

Wetzel v. Eaton Corporation (1973), 62 F.R.D. 22 (D.C. Minn.).

Wilson, Kathleen H. (1980), "The Liability of Pharmaceutical Manufacturers for Unforeseen Adverse Drug Reactions," Fordham Law Review, 48 (April), 735-63.

Ybarra v. Spangard (1944), 25 Cal.2d 486, 154 P.2d 687. 